\title{
Not All about Trends: Persistent Singularities in Election News Coverage
}

\author{
Susana Salgado
}

\section{INTRODUCTION}

This concluding chapter provides an overview of the main features of election news coverage in these six European countries. It intends to address questions such as how is the media coverage of elections done in different countries today? Is there a heavy coverage of elections everywhere? When and why do issues change and how are they covered by the news media? In what ways is news election coverage similar and different in these countries? Are there discernible patterns of election news coverage in these six countries?

This research project was aimed at investigating how the news coverage of national elections looks like in different European countries-in a specific moment in time, when the background international context is similar, much like a snapshot in time - and at identifying the main issues and actors covered by the different types of news media outlets considered in the content analysis (television, newspapers, and papers published only online). This approach allows a characterization and an informed discussion of what election news coverage is in these countries, which could lead

S. Salgado $(\bowtie)$

Institute of Social Sciences, University of Lisbon, Lisbon, Portugal

(C) The Author(s) 2019 165

S. Salgado (ed.), Mediated Campaigns and Populism in Europe, Political Campaigning and Communication, https://doi.org/10.1007/978-3-319-98563-3_8 
to the identification of potential patterns of news coverage. For example, are there discernible trends of election coverage regarding the prevalence of negativity, interpretive journalism, or populist features of political discourse in the news? Finally, this concluding chapter also addresses the implications of the news coverage of elections, as they are made nowadays, on the results of the elections.

All these different elements gain particular relevance when we bear in mind that elections are very important moments in the political life of any country, and in these cases this importance was reflected, for example, in the amount of news coverage devoted to the election campaign. Even though it was slightly greater in some of the countries in the sample (Greece, Portugal, and Spain), which is likely explained by the news outlets' internal editorial criteria, the amount of journalistic attention and of news coverage dedicated to these elections during the official campaign period was considerable in the six countries.

\section{Political Actors and Personalization of Politics in Election News Coverage}

The first significant conclusions are related to personalization and to the political actors that were perceived as the most newsworthy by journalists in Croatia, Greece, Ireland, Poland, Portugal, and Spain. There are important differences regarding the way similar types of news media in these six countries cover what they consider to be the most newsworthy and the most important political actors in the election.

The data analysis shows that, in general, journalists pay more attention to the campaign initiatives and messages of the main parties and their leaders (i.e. the most voted for party in the last election and the parties with more voting intentions in election polls), which therefore receive more news coverage during (at least) the official period of electoral campaign. This was confirmed in all countries included in the sample. However, there are some cases in which the novelty of some parties and candidates is particularly appealing to journalists as it happened in Spain in this election. Although the incumbent Popular Party (PP) and its leader, Mariano Rajoy, had the most media exposure, a considerable degree of attention was also given to the two new parties, Ciudadanos and Podemos and to their leaders, Albert Rivera and Pablo Iglesias, almost the same media coverage that the second largest political party, the Socialist PSOE (Spanish Socialist Workers' Party, Partido Socialista Obrero Español) and its leader Pedro Sánchez have received. The uncertainty about the result that these two 
new parties would be able to achieve in their first parliamentary election, especially after the impressive result of Podemos in the 2014 European Parliamentary election, and speculations about potential future post-election government coalitions motivated a great deal of journalistic coverage (for further details, please see Luengo and Fernández-García in this book).

The journalists' reaction to the uncertainty of the election results and of the political situation that would follow can also be explained by Galtung and Ruge's (1965) news values theory. In short, news values are characteristics of events that determine whether these events become news and trigger audience reactions (Gehrau 2017). News values therefore influence the relative attention and prominence that specific issues, events, and people receive from the news media. Unexpectedness, conflict, and dramatization are among those firstly identified by Galtung and Ruge (1965) and provide background explanation to further understand the reasons why both Podemos and Pablo Iglesias, and Ciudadanos and Albert Rivera received more news media coverage than a larger party, PSOE and its leader Pedro Sánchez, in Spain.

Another potentially important reason for the salience attributed to Ciudadanos and Podemos in the news media has to do with these parties' rapid rise in voting intentions, and with the expectation that they could achieve even more prominent positions in Spanish politics. In fact, in May 2018, opinion polls placed Ciudadanos in first and Podemos in second in the voters' preferences, while the incumbent PP and PSOE (the parties that form the Spanish bipartisanship since 1982) were only in third and fourth place, respectively (for further details, please see Nieto 2018). According to opinion polls carried out in May 2018, the political parties that are openly critical of the system, Ciudadanos and Podemos, represented almost half of the electorate, while PP and PSOE represented less than 40 per cent.

It is also important to note that although we are analysing parliamentary elections - in which political parties are the main players- the focus of most news items, in practically all the countries that were included in the analysis, was on the party leader and not on the political party as a whole. The exception to this trend is Ireland where although there is an overall stated trend towards personalization in election news coverage (for further information, please see Culloty and Suiter in this book), the Irish news media outlets focused less on the party leaders (16 per cent on average) than on parties as a whole in this election in particular. Potential 
explanations for this exception could be related with the organization of the parties' campaigns, the specific personal characteristics of these party leaders, or even with choices made by the journalists when covering the election; however, an additional and different type of research would be necessary to further investigate and explain all underlying reasons behind this result.

In the remaining countries, Croatia, Greece, Portugal, Poland, and Spain, the percentage of news items that focused on the party leaders was always higher than the percentage of journalistic coverage that focused on political parties as the main actor in the news story. For example, the figures range from 66, 54, and 50 per cent in Portugal, Greece, and Croatia, respectively (for further details, please see Salgado; Papathanassopoulos and Giannouli; Mustapić et al. in this book).

Political party leaders were also the preferred source of information for journalists in Croatia, Portugal, and Spain, but not so much in Poland and Ireland where journalists resorted more often to their own professional class as source of information about the election, thus mostly covering the parties' campaign with reports of facts and events rather than giving more space to political party leaders and to their direct quotes on the election campaign actions, policy proposals, ideological stances, and so on (for further details, please see Stępińska et al. and Culloty and Suiter in this book).

The increasing concentration of election news media coverage on a limited number of political actors and the preference to report the political leaders' actions and statements instead of the political parties as a whole is well documented in research and has been referred to with different concepts, including personalization of politics (McAllister 2007; Kriesi 2012), or as presidentialization of (parliamentary) politics (Mughan 2000; Poguntke and Webb 2005). The high visibility of personalities in the news media can also be tied to leadership focused strategies and potentially to some specific forms of populism.

In fact, populism has been linked in research to media logic and personalization (Kriesi 2015) and to strong leadership strategies (Weyland 2001). However, despite these indications, the present study did not point to any direct connection between strong personalization of politics in the media and populism. Except in Ireland, the levels of personalization of politics in the election news coverage were high in all countries, but this was observed in countries where populist actors were successful in elections (e.g. Poland and Greece) and in countries where the exact opposite has happened (e.g. Portugal). 


\section{The Election Campaigns’ Most Salient Issues}

The variables intended to study the issues discussed during the election campaign were focused on the journalistic report of the campaign and were designed to identify and code the dominant issue in each news item. Therefore, this also means that other issues could also have been present both in the political parties' messages and in the news items, but the content analysis only coded the ones that received greater prominence in the news story and that were thus highlighted more often in the news coverage.

Election campaigns are usually pivotal moments for candidates to explain their ideological stances and their policy proposals to tackle the existing problems, so it would make sense that this would be somehow reflected in the journalistic coverage of the election campaign. However, in many cases the space attributed to specific policy issues is marginal when compared to the attention dedicated to campaign strategy and events, to the candidates' performance in electoral debates, or to opinion polls, for example. In fact, topics related to "party politics and campaigning" were by far the most prevalent in the news media coverage of the Croatian, Irish, Polish and Spanish elections.

Portugal and Greece were interesting exceptions, as issues had more preponderance and the issue frame overcame the strategy frame in these two countries' election news coverages. Greece and Portugal were severely affected by the Euro Crisis and this challenging conjuncture had a huge impact on both their societies and politics. Therefore, it is not surprising that the Euro Crisis as an issue was particularly salient in the Portuguese and Greek election campaigns. More surprising, however, was the fact that the Euro Crisis was not important in Ireland and Spain, which is possibly explained by the different framing (and management) that the Euro Crisis issue had in Spain and to the fact that Ireland had exited the financial assistance programme more than three years before the 2016 election, in 2013.

Although the differences between the two types of news framing were not substantial both in Portugal and in Greece, they are still noteworthy because they run counter the trend, often presented as transnational, of politics in general and elections in particular being mostly reported by journalists through a strategy news frame. In Greece, the percentage of news items in which the issue frame was considered by coders to be the dominant news frame was 54.4 per cent, and in Portugal it was slightly higher, 57.4 per cent. 
In Portugal, the results should be partly related to the 2011 bailout, the recent economic reforms and the austerity measures that the country underwent, and the overall impact that the Euro Crisis had on Portuguese society and politics. In this country, public finances, the state of the economy, social affairs, as well as the Euro Crisis itself (e.g. the effects of austerity and the way to move forward) had a special prominence in the news coverage of the 2015 election campaign and preceded in salience news items that were mainly focused on party politics and on campaign strategy. Although the state of the economy and the slow economic growth have been a prevalent issue in most recent elections in Portugal (Salgado 2007, 2009), the context of a serious economic crisis seems to have further emphasized the prevalence of both these topics and of actual policy discussion in the 2015 election campaign, thus confirming their major importance both for politicians and for journalists.

As Culloty and Suiter (this book) and Luengo and Fernández-García (this book) have explained in their chapters, something similar occurred in the immediate aftermath of the Euro Crisis in Ireland and Spain. In Ireland, for example, almost 60 per cent of the newspaper coverage of the 2011 election campaign was devoted to policy, economy, and issues in general; but the interest in these topics dropped substantially in the general election that followed in 2016. In Portugal, given the lingering economic stagnation and hardship, the economic affairs have maintained their importance in political and public debates over the last few years, and have emerged as particularly significant during election campaigns.

Situations of crisis thus seem to impact on the type of news media coverage that is made of election campaigns. As economic crises drive the political debate and the news coverage towards economy and finance-related issues and policies; a major defence challenge, such as terrorism, should inflect attentions towards international relations, foreign policy, and defence issues; and political crises should instead boost debates and coverage focused on party politics, party conflicts, the functioning of democracy and political system reforms, government and parliamentary coalitions, and democratic governance in general. When there is no specific and pressing social or political problem, substantiated in a major crisis, the news coverage of the election should end up being less focused on issues and policy and more on the political candidates' competition and each one of them chances of winning, in other words, based on strategy and game news framing (i.e. "horse race" news coverage). 
As noted, the most common news framing used in the journalistic coverage of elections in the majority of the countries included in this study (Croatia, Ireland, Poland, and Spain) was the strategic news frame. This type of news coverage focuses specifically on the logic of competition, namely the election "horse race", the winning versus losing dynamics; on the candidates and political parties' strategies and tactics to win the election or to gain advantages over their opponents; and on the overall support that political candidates and parties have managed to gather among public opinion, including their standing in opinion polls (for further details on the strategic news framing, see Aalberg et al. 2012).

The figures have shown that the prevalence of the strategic news frame ranged from 75 per cent in Croatia and 73 per cent in Ireland to 46 per cent in Greece and 44 per cent in Portugal. The percentages in Spain and Poland were 62 and 59 per cent, respectively. This means that in four of the six countries under analysis, election news stories were mostly framed through the logic of strategy in politics. An explication for the Portuguese and Greek exceptions was already put forward, but it should also be explained that the study coded the dominant news frame, which basically means that when the issue frame was dominant, the strategic frame could also be present, and vice versa. In other words, in some cases, news items could contain both types of news frames, but only the dominant (the one included in the lead of the news story and/or taking more space or time overall) was coded.

Another interesting finding is related with the type of media that seems to be less prone to cover elections and electoral campaigns focusing on strategy: the prevalence of the strategic news frame was overall lower in online news outlets. The fact that the online news media outlets have fewer limits in terms of space allows them to publish not only longer news stories but also more news pieces about specific issues, as well as on topics and political actors that are not usually covered by mainstream newspapers and television channels. For example, it was not unusual to find news items published in the online news media containing all (or at least most of) the political parties' main positions on specific issues and their policy proposals. This allows us to conclude that the online news media have broadened the space dedicated to issues and policy discussions, at least during election campaigns, which is the time frame of this study.

Moreover, during the official campaign period, both mainstream newspapers and television channels typically prepare daily summaries of 
the campaign that tend to favour the focus on the winning and losing logic, which is believed to attract the interest of a wider audience. The online news media outlets do not have these limitations and can publish all the news items they want around the clock (of course within the limits of their human resources). All of these reasons contribute to explain the greater focus of online news media on issues and their greater use of issue news frame. The differences between strategic and issue frame vary according to countries, but are far more substantial in some cases, for example, Greece, where the difference is between 29 per cent of news items focusing mainly on issues in newspapers and 68 per cent in online news media outlets.

Also included in the logic of the strategy news framing, the publication of opinion polls during the election campaign was analysed separately in the study in order to check its own specific salience in the news coverage of elections in the different countries. This variable in particular was designed to capture any potential self-reflection of journalists regarding the impact of opinion polls in the election campaign (on metacommunication about media manipulation in general see e.g. Esser et al. 2001). The coding of this variable in particular was thus intended to assess the prevalence of opinion polls as an issue in the news media coverage, and refers, for example, to discussions about the release of opinion polls during the campaign and/or to discussions on the effects of opinion polls on the election campaign (e.g. on the relations between political opponents or on the overall campaign momentum), and even on the potential outcome of the election.

The impact that political opinion polls may have on elections has been raising concerns in democracies throughout the world over the last few decades. Alongside the opinion polls' immediate purpose of measuring the voters' opinions lays also its controversial potential to influence opinions (see e.g. Bogart 1988; Price and Stroud 2006). In addition, as opinion polls might also include some degree of bias (the polling companies or news media's political bias, but not only), the release of their results can, on some occasions, be aligned with specific political agendas that have interests in influencing the voting behaviour and/or the voters' political perceptions.

News items discussing the opinion polls results and effects (e.g. contextualization and interpretation) had a relatively important presence in the election news coverage in some of these countries. These specific elements were prevalent, for example, in 10 per cent of the news coverage in 
Portugal; in 6 per cent of the news items in Ireland (interestingly, almost as much as news items that focused on macro-economics and social affairs, which were 7 per cent); and in 5 per cent of the Greek news stories, which, in this case, was more than the news items that were focused on discussing the much needed national unity and the potential government coalitions that could result from the election results (3.2 per cent).

\section{Different Expressions of Populism}

The time frame of this study coincided opportunely with some significant populism-related events in Europe. In 2015, political parties and party leaders considered populist were re-elected in Greece (the left-wing political party Syriza and its leader Alexis Tsipras) and elected in Poland (the right-wing political party Law and Justice, Prawo i Sprawiedliwość, PiS). In the Polish case, the victory of the right-wing Populist Party Law and Justice in the 2015 parliamentary election was also the first parliamentary majority in the country's democratic history since 1989.

Greece has not been strange to populism and long before Alexis Tsipras and Syriza's election, Greek politics had already a long record of populist political parties and of populist political leaders (see e.g. Vasilopoulou et al. 2014; Vasilopoulou and Halikiopoulou 2015; Papathanassopoulos et al. 2017; Stavrakakis and Katsambekis 2018). In addition to Syriza and Alexis Tsipras, other examples of Greek populist political actors include the ultra-nationalist Golden Dawn, the conservative right-wing ANEL (Independent Greeks), or Andreas Papandreou's PASOK (Panhellenic Socialist Movement) in the 1970s. In Poland, extant literature has identified populist political actors and waves of populism almost since the beginning of its democracy (see e.g. van Kessel 2015; Stępińska et al. 2017). Polish examples include Self Defence (Samoobrona Rzeczpospolitej Polskiej, SO) since 2001, Law and Justice (PiS) since 2005, as well as the most recent (2015) political movement Kukiz'15 (led by Paweł Kukiz). The far-right The League of Polish Families (Liga Polskich Rodzin, LPR) is often considered to be a populist political actor as well.

Also noteworthy and particularly interesting for research is the fact that the 2015 election was the first parliamentary election in Croatia after the country joined the European Union in 2013. The election happened while Croatia was simultaneously facing the two crises that have been mostly associated to the recent surge of populism in Europe: the country was experiencing economic hardship and the challenge of the migration or 
refugee crisis in its own territory (the Croatian government allowed refugees to cross the country in their journey to Western Europe). The decisions of the Croatian government regarding the migration crisis ended up having less impact on the election than on the country's relations with the neighbouring countries, Hungary, Slovenia, and Serbia. In fact, this crisis and the government policy did not seem to favour the right-wing arguments and position: the right-wing populist Croatian Civic Party lost the two-seats parliamentary representation that it had secured in the previous election (2011) as part of the pre-election coalition with the Croatian Democratic Union.

Whereas some countries in the sample seem to have been somehow immune to Europe's recent populist wave (e.g. Ireland and Portugal)—at least considering the electoral success and the actual election of populist political parties and leaders - and to the destabilization of their party systems (Hernández and Kriesi 2016); other countries have often been presented as prime examples of Europe's turn towards populism (Greece and Poland), even if they illustrate very different types and different degrees of populism (for further discussion about the manifestation of different types and degrees of populism, see e.g. Jagers and Walgrave 2007; Salgado and Stavrakakis 2018; Salgado 2018).

The fact that citizens in some countries do not vote for populist parties and populist political leaders to rule the country does not mean, however, that we cannot find elements of populism in the election campaign and in the news coverage of the election. It is thus very relevant to compare the type and degree of populist messages in the coverage of election campaigns in countries where populist parties were elected with the countries where populist parties did not have any electoral success.

This approach assessed the prevalence of populism in the election news coverage through a content analysis that comprised different elements of populist rhetoric. The analysis included the most common features of populism: references to the people (expressing closeness and belonging to the people; speaking on behalf of the people); a divide between the "us and them"; references to anti-elitism, anti-establishment, and anti-system; and exclusion of out-groups. In order to get a more complete picture of the different dimensions of populist rhetoric, the analysis has also included other typical elements of populist political discourse, such as the oversimplification of issues, which involves for example the resort to Manichaeism (e.g. good vs. bad, right vs. wrong) and scapegoating and blame shifting discourse strategies. 
The content analysis results did not point to any discernible common trends in these six countries regarding the populist elements that were most used by political actors in their campaign messages and that were covered by the news media. The exclusionary discourse, substantiated in the division between "us" and "them", was overall the most common feature of populism in the election news coverage; it was used by the majority of politicians in Poland, Spain, Croatia, and Greece. A superficial analysis might suggest an overall greater success of this type of representation of society as populist political actors that have resorted to the "us versus them" rhetoric have experienced some degree of electoral success, while in the countries in which this strategy was less prevalent, populist political actors had less or no electoral success at all (e.g. Portugal and Ireland).

Typically, news media outlets reproduce the political discourses, but they also contribute to construct ideas and perceptions when certain assumptions about reality (and in this case about exclusion and the otherness) are reaffirmed discursively through the news coverage. This basically means that even in the cases when the news media outlets are simply reproducing the politicians' political messages, they can still be, in part, (indirectly) responsible for the deterioration of election debates. This certainly raises important ethical challenges to journalism's duty to report.

The use of the word "people" by political candidates to express closeness and belonging to the people, and as a rhetorical tool to emphasize their differences compared to other candidates, for example, was the most common feature of the populist discourse in Portugal. In Ireland the main populist feature was anti-elitism; although it was not often used (it was found in only in 2 per cent of the news items). The anti-establishment view was a strong component of electoral discourse in Greece, and it was a strategy used mainly by new political actors to distinguish themselves from the political leaders who had ruled the country before the crisis. In Poland, the exclusion of out-groups was the most prevalent feature, and ostracization was mainly directed towards immigrants. Finally, the notion of an idealized nation had greater prominence in Spain ( 5 per cent), which is explained by the ongoing debate on the independence of Catalonia, Galicia, and the Basque Country, and is directly linked to the contrasting identification of nationalists and separatists as political out-groups menacing Spain's stability and unity.

It is also worth noting that newer political parties in general tend to frame their political communication and political strategies around the use of anti-establishment rhetoric (these cases were found in Spain, Croatia, 
Greece, and Poland). This is not surprising if we consider that although these political parties are running for elections (and therefore implicitly accepting the system or attempting to change the system from the inside), it is easier for them to maintain an anti-establishment stance because they have no government experience and therefore they are not viewed as part of the establishment. If and when they are elected, these political actors have to adjust their discourse or at least redefine what the establishment is, in their view.

The other specific features of populist communication and rhetoric that were included in the study, such as the over-simplification of issues, and blame shifting and scapegoating were also more prevalent in the newer political parties. One possible explanation for this is the fact that these parties were attempting to deliver a different approach to politics, but one that could also be understandable by all those who do not feel represented by mainstream politics and who are distrustful of political elites. Presenting the issues and the corresponding solutions as simpler than they are in fact might well be a means of seeking an advantage over the opponents through the use of straightforward communication, as an attempt to engage and convince more voters.

The news coverage of these national elections in Portugal and Ireland reflects the low prevalence of populism not only in these countries' political systems but also in their news media outlets. In Portugal, for example, most of the news items coded as containing any of the features of populism resulted from the news coverage of statements by politicians. Although the sample only included a limited amount of news media outlets per country (nine in most cases, including centre-left and centre-right political leaning and reference and tabloid newspapers, public and private television channels, and newspapers that are only published online), it is diversified and complete enough to allow an overall picture of the news media coverage in each of these countries.

Ireland and Portugal challenge some generally accepted theses that sustain that the commercialization in the media sector tends to boost populism in the media (e.g. Mazzoleni 2008; Meyer apud Krämer 2014). Populism in the media is seen as a consequence of news media outlets that pursue higher circulation and ratings above all else. Even though oversimplification of reality and sensationalism are intrinsic characteristics of media grammar, which have been further enhanced by the commercialization trend in the media sector, they are not necessarily synonym with populism, or at least with the features of populism addressed in this research. 
Portugal and Ireland also challenge the premise that situations of crisis lead to the success of populist political actors and ideas (e.g. Kriesi 2014, among others). Portugal and Ireland were among the countries that have suffered the most with the Euro Crisis; however, both the levels of electoral success of populist political parties and the prevalence of populist discourses in politics and in the news media in these two countries were in general very low when compared with the other countries in the sample. These two cases confirm McDonnell's (2008) interpretation in regard to the Irish case and Salgado and Stavrakakis's (2018) analysis, as well as the "fuzzy relationship" between crisis and populism that Tappas and Kriesi (2015) have suggested; but most importantly this also draws attention to the fact that Southern Europe should not be treated as an unique entity, as Southern European countries (the ones that were included in our sample: Portugal, Greece, and Spain) display many important differences among them.

Regarding the type of media that seems to be more prone to disseminate populism, the content analysis has shown that online news media were more likely to include news containing populist features. Different factors might enhance specific characteristics of journalism, such as oversimplification or over-personalization of politics, which are more conducive to the diffusion of populism, among them, for example, the following: news are produced and consumed much faster now when compared with just a few years ago; online news stories are often written to be clicked, "liked" and "shared" as much as possible; journalistic content is aimed at gaining a fast and wide distribution to reach more audience, including outside national borders, which often means the use of simple, appealing language and more visuals; and finally news items are often linked to other news stories and especially to comments sections to be used by the general public (the people) that is presumably populist by nature.

It is also important to stress that in addition to the type of media, the prevalence of populist features in the news coverage is, in some cases, also related with the ownership of news media outlets. Although our sample does not illustrate these examples sufficiently, Italy (e.g. with Berlusconi) and the Czech Republic (with Andrej Babiš) are cases of media ownership being determinant in the definition of a populist style of news coverage of politics (regarding the Italian case, see, e.g. Mancini 2011; and for the Czech case see, e.g. Císař and Štětka 2017).

The Croatian case presents a different but interesting singularity regarding the links between media and politics in populism. From the six 
countries analysed in the study, Croatia was the only one illustrating a situation in which the media elite was clearly identified in anti-elitism rhetoric, which points to a clear divergence between some politicians and journalists. This type of open dispute between a few politicians and some journalists has potential to cause the enhancement of some specific features in the media coverage of politics, namely it might increase negativity in the political news, as well as the prevalence of journalistic interpretation in the news reports, for example.

\section{INTERPRETATION AND NEGATIVITY}

The journalistic coverage of these six parliamentary elections was mainly neutral and negative. However, there are important cross-country variations regarding the prevalence and the source of negativity. For example, it can originate in journalists through opinion and analysis pieces for example, or in negative and confrontational attitudes of the political candidates in the election campaign, which journalists merely report in their news coverage.

For example, in Croatia, where nearly 30 per cent of the news items had a predominantly negative tone, most negativity came from the news media outlets themselves that expressed criticism towards the campaigning political candidates and towards the political system in general (Mustapić et al. this book). Similarly, Stępińska et al. (this book) observed in Poland that nearly one-third of the election news coverage had mainly a negative tonality, which the authors explain with the highly critical approach of journalists to the election campaign and politics in general.

Focusing on Ireland, Culloty and Suiter (this book) explain the overall absence of political news coverage with a positive tone in a similar manner, because of the widespread anti-politics bias and of the enduring nonpartisan role of the Irish news media. But in Portugal, for example, although an important share of negativity comes from opinion and analysis (Salgado this book), which suggests that the sources are either journalists or columnists; the overall higher prevalence of negativity in plain news stories points to the confrontational nature of the political campaign as a relevant factor in intensifying negativity in the news, which is a type of negativity that journalists are merely reporting and that is not initiated by them personally.

As to the type of news media outlets that have covered the election campaign in a more positive or in a more negative manner, the data analysis 
did not show any clear similarities in these countries. In some countries, it is mainly the online news media outlets that cover politics with a positive tone (e.g. Poland), while in others it is exactly the opposite (e.g. Portugal). In addition, whereas Greek and Spanish newspapers were the most negative in their countries, in Portugal, both mainstream newspapers and television channels covered the political campaign mainly with a neutral tone. The prevalent tone in the news coverage thus seems to be more linked to the media outlets' ownership and to their political leaning than to the type of media (online, printed press, television).

Negativity is often related to the presence of journalistic interpretation in the news: the journalists' more prominent role in the news coverage of politics often results in more negativity (for a summary of research specifically focused on this topic, see Salgado and Strömbäck 2012). The prevalence of journalistic interpretations in the media coverage of the election campaigns in these six countries ranged from 15 per cent (the lowest percentage) in Poland to 53 per cent (the highest percentage) in Ireland (some intermediate values were e.g. Spain 47 per cent, Portugal 31 per cent, and Greece 22 per cent).

The content analysis did not show any clear trend regarding the type of media that tends to include more interpretive journalism in the election news coverage. While in Portugal and Ireland the media with the highest percentage of interpretive journalism was television, in Greece and Spain, newspapers had overall the most prevalence of journalist interpretations in the election news coverage.

There are, however, some important similarities in all of these countries. One is the fact that journalistic interpretation is also present in plain news stories. Another similarity is related to the type of journalistic interpretation, that is, journalistic explanations, journalistic speculations, or overt commentaries. In the six countries, the most common type of journalistic interpretation was, according to this data analysis, journalistic explanations or interpretations of the reasons behind events or actions.

Although it is not possible to argue that interpretive journalism is growing or decreasing in the news coverage of elections on the basis of this study, as it is not longitudinal, it is still possible to conclude that even though in differing degrees, interpretive journalism is present in election news coverage in all these countries. Quite probably it is present, to a lesser or greater extent, in election news coverage in most European countries, as previous research has shown in the news coverage of politics during routine periods (Salgado et al. 2017). 


\section{CONCLUSION}

This research approach was designed to investigate how elections are covered by journalists in different European countries, in a similar time span, by testing specific concepts and trends that were previously put forward in relevant, existing literature.

News values that are used in the selection and framing of political news have been pointed out as features of political news coverage by some authors. These are for instance some of the concepts that have guided this approach. The construction of political news as conflict and drama (Bennett 1996), an overall emphasis on the idea of competition (e.g. horse race, see Broh 1980; Mutz 1995) rather than on substantive issues, negativity (e.g. Patterson 1993; Cappella and Jamieson 1997), overpersonalization of politics (even though contested by some authors as, e.g. Karvonen 2010; Kriesi 2012), and an increasing interest in the political candidates' image and in their personal characteristics (Nimmo and Savage 1976; Hacker 1995) put the emphasis on political leaders rather than on institutions and parties, and shift the manner in which political candidates are evaluated by journalists and voters.

It is thus not uncommon to read and hear that local political and journalistic cultures have been replaced by transnational trends. There are, in fact, important global trends and features influencing national political and media systems and thus impacting on the news coverage of politics and elections (e.g. Swanson and Mancini 1996; Swanson 2004). However, as the present data analysis has shown, significant local specificities remain relevant and should also be given proper attention, to avoid ignoring potentially enlightening information that could contribute to the further understanding of the links between politics and media in the coverage of election campaigns.

The attempt to infer general knowledge and generate a greater level of generalization based on this data analysis was often hampered by the singularity of these countries in many respects, as we have seen. It was not possible to identify clear regional (or other) patterns on the concepts that were tested empirically. The research results were often mixed, did not point to clear regional patterns, but they have illustrated relevant country specificities (see e.g. the results of the data analysis on personalization of politics, populism, or the dominant news framing, just to mention a few cases). However, this does not mean that the research results cannot inform knowledge on election news coverage in Europe. In fact, 
this draws attention to the continuing need to rethink concepts and to adjust our theoretical models to constantly changing media and political environments.

Although the salience of some transnational trends in today's news media coverage of politics and elections has emerged in the analysis (e.g. personalization of politics, negativity), there was always an outlier or exceptions that pointed to the importance of the countries' specific political, social and cultural context. These often conflict with the transnational trends of news coverage that are presented as global (e.g. the Portuguese and Greek exceptions in the dominant news framing). This suggests relevant varying gradations and, in some situations, even important exceptions that should be identified and explained whenever possible.

Singularities should therefore be acknowledged in order to complement our understandings of how and why different news media cover election campaigns the way they do. This is a field of studies that although has already seen important contributions, it is still lacking systematic empirical research to test the many theoretical assumptions that underpin most current knowledge on the links between media and politics. But within this effort to further advance empirical research, the presence and relevance of singularities should also be assessed, as it can contribute to a better understanding of these issues.

\section{REFERENCES}

Aalberg, T., Strömbäck, J., \& de Vreese, C. (2012). The framing of politics as strategy and game: A review of concepts, operationalizations and key findings. Journalism, 13(2), 162-178.

Bennett, W. L. (1996). An introduction to journalism norms and representations of politics. Political Communication, 13(4), 373-384.

Bogart, L. (1988). Polls and the Awareness of Public Opinion (2nd ed.). New Brunswick, NJ: Transaction.

Broh, C. A. (1980). Horse-Race journalism: Reporting the polls in the 1976 presidential election. The Public Opinion Quarterly, 44(4), 514-529.

Cappella, J. N., \& Jamieson, K. (1997). Spiral of Cynicism. The Press and the Public Good. New York: Oxford University Press.

Císař, O., \& Štětka, V. (2017). Czech Republic: The rise of populism from the fringes to the mainstream. In T. Aalberg, F. Esser, C. Reinemann, J. Strömbäck, \& C. de Vreese (Eds.), Populist Political Communication in Europe (pp. 285-298). London and New York: Routledge. 
Esser, F., Reinemann, C., \& Fan, D. (2001). Spin doctors in the United States, Great Britain, and Germany: Meta-communication about media manipulation. The Harvard International Journal of Press/Politics, 6, 16-45.

Galtung, J., \& Ruge, M. (1965). The structure of Foreign news. Journal of Peace Research, 2(1), 64-90.

Gehrau, V. (2017). News values: Audience effects. In P. Rössler, C. A. Hoffner, \& L. Zoonen (Eds.), The International Encyclopedia of Media Effects. Wiley Online Library. https://doi.org/10.1002/9781118783764.wbieme0054.

Hacker, K. L. (Ed.). (1995). Candidates Images in Presidential Elections. London: Praeger.

Hernández, E., \& Kriesi, H. (2016). The electoral consequences of the financial and economic crisis in Europe. European Journal of Political Research, 55(2), 203-224.

Jagers, J., \& Walgrave, S. (2007). Populism as political communication style: An empirical study of political parties' discourse in Belgium. European Journal of Political Research, 46(3), 319-345.

Karvonen, L. (2010). The Personalization of Politics: A Study of Parliamentary Democracies. Colchester: ECPR Press.

Krämer, B. (2014). Media populism: A conceptual clarification and some theses on its effects. Communication Theory, 24(1), 42-60.

Kriesi, H. (2012). Personalization of national election campaigns. Party Politics, $18(6), 825-844$.

Kriesi, H. (2014). The populist challenge. West European Politics, 37(2), 361-378.

Kriesi, H. (2015). Populism: Concepts and conditions for its rise in Europe. Comunicazione Politica, 2, 175-194. https://doi.org/10.3270/80551.

Mancini, P. (2011). Between Commodification and Lifestyle Politics. Does Silvio Berlusconi provide a New Model of Politics for the Twenty-First Century? Oxford: Reuters Institute for the Study of Journalism.

Mazzoleni, G. (2008). Mediated populism. In W. Donsbach (Ed.), The International Encyclopedia of Communication. Wiley Online Library. https:// doi.org/10.1002/9781405186407.wbiecm057.

McAllister, I. (2007). The personalization of politics. In R. J. Dalton \& H.-D. Klingemann (Eds.), Oxford Handbook of Political Behavior. Oxford: Oxford University Press.

McDonnell, D. (2008). The Republic of Ireland: The Dog that hasn't Barked in the Night? In D. Albertazzi \& D. McDonnell (Eds.), Twenty-first Century Populism. The Spectre of Western European Democracy (pp. 198-216). Basingstoke: Palgrave.

Mughan, A. (2000). Media and the Presidentialization of Parliamentary Elections. Basingstoke: Palgrave.

Mutz, D. C. (1995). Effects of horse-race coverage on campaign coffers: Strategic contributing in presidential primaries. The Journal of Politics, 57(4), 1015-1042. 
Nieto, A. (2018, May 14). Caída histórica de PP y PSOE debido al auge de los nuevos partidos [Historic fall of PP and PSOE due to the surge of the new parties]. In newspaper El Pais. Retrieved from https://politica.elpais.com/politica/2018/05/13/actualidad/1526222522_428410.html.

Nimmo, D., \& Savage, R. L. (1976). Candidates and Their Images: Concepts, Methods, and Findings. Pacific Palisades, CA: Goodyear Publishing.

Papathanassopoulos, S., Giannouli, I., \& Andreadis, I. (2017). Greece: Populism between left and right. In T. Aalberg, F. Esser, C. Reinemann, J. Strömbäck, \& C. de Vreese (Eds.), Populist Political Communication in Europe (pp. 195-206). London and New York: Routledge.

Patterson, T. E. (1993). Out of Order. New York: Knopf.

Poguntke, T., \& Webb, P. (2005). The Presidentialization of Politics: A Comparative Study of Modern Democracies. Oxford: Oxford University Press.

Price, V., \& Stroud, N. J. (2006). Public attitudes toward polls: Evidence from the 2000 U.S. Presidential Election. International Journal of Public Opinion Research, 18(4), 393-421. https://doi.org/10.1093/ijpor/edhl19.

Salgado, S. (2007). Os Veiculos da Mensagem Politica. Estudo de uma campanha eleitoral nos media (The Vehicles of Political Communication. Studying an Electoral Campaign in the Media). Lisboa: Livros Horizonte.

Salgado, S. (2009). Os media e as eleições em Portugal: estudo da cobertura noticiosa das legislativas de 2005 e das presidenciais de 2006 (Media and Elections in Portugal: Studying the News Coverage of the 2005 Legislative Election and of the 2006 Presidential Election). In M. Costa Lobo \& P. Magalhães (Eds.), Legislativas 2005 e Presidenciais 2006 (pp. 39-74). Lisboa: Imprensa de Ciências Sociais.

Salgado, S. (2018). Where's populism? Online media and the diffusion of populist discourses and styles in Portugal. European Political Science. https://doi. org/10.1057/s41304-017-0137-4.

Salgado, S., \& Stavrakakis, Y. (2018). Introduction: Populist discourses and political communication in Southern Europe. European Political Science. https:// doi.org/10.1057/s41304-017-0139-2.

Salgado, S., \& Strömbäck, J. (2012). Interpretive journalism: A review of concepts, operationalizations and key findings. Journalism, 13(2), 144-161.

Salgado, S., Strömbäck, J., Aalberg, T., \& Esser, F. (2017). Interpretive journalism. In C. de Vreese, F. Esser, \& D. Hopmann (Eds.), Comparing Political Journalism (pp. 50-70). London and New York: Routledge.

Stavrakakis, Y., \& Katsambekis, G. (2018). The populism/anti-populism frontier and its mediation in crisis-ridden Greece: From discursive divide to emerging cleavage? In S. Salgado \& Y. Stavrakakis (Eds.), Populist Discourses and Political Communication in Southern Europe, European Political Science. https://doi. org/10.1057/s41304-017-0138-3. 
Stępińska, A., Lipiński, A., Hess, A., \& Piontek, D. (2017). Poland: A fourth wave of populism? In T. Aalberg, F. Esser, C. Reinemann, J. Strömbäck, \& C. de Vreese (Eds.), Populist Political Communication in Europe (pp. 311-325). London and New York: Routledge.

Swanson, D. (2004). Transnational trends in political communication: Conventional views and new realities. In F. Esser \& B. Pfetsch (Eds.), Comparing Political Communication (pp. 45-63). Cambridge: Cambridge University Press.

Swanson, D., \& Mancini, P. (1996). Politics, Media, and Modern Democracy. An International Study of Innovations in Electoral Campaigning and Their Consequences. London: Praeger.

Tappas, T. S., \& Kriesi, H. (2015). Populism and crisis: A fuzzy relationship. In H. Kriesi \& T. S. Pappas (Eds.), European Populism in the Shadow of the Great Recession (pp. 303-325). Colchester: ECPR Press.

van Kessel, S. (2015). Populist Parties in Poland. In S. van Kessel (Ed.), Populist Parties in Europe. Agents of Discontent? (pp. 121-143). London: Palgrave Macmillan. https://doi.org/10.1057/9781137414113_5.

Vasilopoulou, S., \& Halikiopoulou, D. (2015). The myth of national rebirth: The Golden Dawn's populist ultra-nationalism. In S. Vasilopoulou \& D. Halikiopoulou (Eds.), The Golden Dawn's 'Nationalist Solution': Explaining the Rise of the Far Right in Greece (pp. 64-77). New York: Palgrave Macmillan. Vasilopoulou, S., Halikiopoulou, D., \& Exadaktylos, T. (2014). Greece in crisis: Austerity, populism and the politics of blame. Journal of Common Market Studies, 52(2), 388-402. https://doi.org/10.1111/jcms.12093.

Weyland, K. (2001). Clarifying a contested concept: Populism in the study of Latin American politics. Comparative Politics, 34(1), 1-22.

Open Access This chapter is licensed under the terms of the Creative Commons Attribution 4.0 International License (http://creativecommons.org/licenses/ by $/ 4.0 /)$, which permits use, sharing, adaptation, distribution and reproduction in any medium or format, as long as you give appropriate credit to the original author(s) and the source, provide a link to the Creative Commons license and indicate if changes were made.

The images or other third party material in this chapter are included in the chapter's Creative Commons license, unless indicated otherwise in a credit line to the material. If material is not included in the chapter's Creative Commons license and your intended use is not permitted by statutory regulation or exceeds the permitted use, you will need to obtain permission directly from the copyright holder.

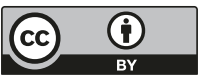

